$5-28-2021$

\title{
Dossier: Uyghur Women in China's Genocide
}

Rukiye Turdush

Uyghur Research Institute

Magnus Fiskesjö

Cornell University

Follow this and additional works at: https://digitalcommons.usf.edu/gsp

\section{Recommended Citation}

Turdush, Rukiye and Fiskesjö, Magnus (2021) "Dossier: Uyghur Women in China's Genocide," Genocide Studies and Prevention: An International Journal: Vol. 15: Iss. 1: 22-43.

DOI:

https://doi.org/10.5038/1911-9933.15.1.1834

Available at: https://digitalcommons.usf.edu/gsp/vol15/iss1/6

This Dossier is brought to you for free and open access by the Open Access Journals at Digital Commons @ University of South Florida. It has been accepted for inclusion in Genocide Studies and Prevention: An International Journal by an authorized editor of Digital Commons @ University of South Florida. For more information, please contact digitalcommons@usf.edu. 


\title{
Dossier: Uyghur Women in China's Genocide
}

\author{
Rukiye Turdush \\ Uyghur Research Institute \\ Ankara, Turkey \\ Magnus Fiskesjö \\ Cornell University \\ Ithaca, New York, USA
}

\section{Introduction}

The aim of genocide is to intentionally destroy a group, in whole or in part, targeting the group as a race, ethnicity, religion, and/or culture, and not specifically in terms of gender. Like in many other cases, China's genocide against the Uyghurs and other Turkic Muslims aims to destroy the group, in whole or in part. However, the genocide's process and implementation are very different from other genocides. This article focuses on China's implementation of genocidal policies against Uyghur women, which stands out in several respects. Analyzing gender-based cases of the Uyghur genocide is not intended simply to prioritize female victims over male victims. Rather, it is done to better understand China's crimes, and create practical protocols to prevent genocide. Through an examination of first-hand victim interviews, ${ }^{1}$ reports, Chinese state media and western media, and probing Chinese philosophy as a source of the ideology behind the genocide, the authors focus specifically on Uyghur women in order to discuss the following questions: How do gendered policies targeting Uyghur women expose the Chinese government's genocidal intention in East Turkistan? As a root cause of this genocide, how is Chinese colonialism reflected in the policies implemented against Uyghur women and, particularly in the implementation processes that use the tools of punishment borrowed from Legalism?

\section{Policies against the Uyghur Women: Genocidal Intent}

China's gender-based policies, including policies to prevent births, state-sponsored forced marriages, forced labor, and the policy of appointing male Han Chinese cadres to Uyghur homes, as well as mass rape camps which we discuss in this article, expose China's intent to commit genocide as a direct outcome of its colonialism. All of these acts committed by China's government today are self-evident, and the results are predictably destructive.

Behind these actions, we address the systematic character of the planning, policymaking, and repetitive implementation of these policies, which are all directed toward the same final outcome. The International Criminal Tribunal for Rwanda (ICTR) mentioned how "existing plans would be strong evidence of the specific intent requirement for the crime of genocide." 2 While the Chinese government's plans do not explicitly advertise genocide but are instead couched in the language of re-education, employment skill training, pair up relatives for ethnic unity, family planning, development, and the like, their destructive effect is plainly evident. It is achieved by planning, budgeting, and allocating resources and personnel to enforce and carry out these plans. The Chinese government openly insists upon these policies as one hundred

\footnotetext{
${ }^{1}$ All interviews conducted by the first author were confidential. To protect the interviewees' identities, the author and select interviewees have mutually agreed to use aliases (indicated with an asterisk *) and/or redact their last names (indicated with an obelisk + ). Where no special symbols appear, interviewees' original names were retained.

2 The Prosecutor v. Clément Kayishema and Obed Ruzindana, Trial Judgement, May 21, 1999, International Criminal Tribunal for Rwanda (ICTR), ICTR-95-1-T, para. 276, accessed April 13, 2021, https://www.refworld.org/ cases,ICTR,48abd5760.html.
}

Rukiye Turdush and Magnus Fiskesjö. "Dossier: Uyghur Women in China's Genocide." Genocide Studies and Prevention 15, no. 1, 22-43. https://doi.org/10.5038/1911-9933.15.1.1834.

(c) 2021 Genocide Studies and Prevention. 
percent correct and plan to continue them. ${ }^{3}$ Before discussing the root causes of China's genocidal intent, we examine each policy aspect, laying out the evidence for how these policies are repeatedly implemented and have devastating consequences.

\section{Horrific Outcome of the so-called Family Planning Policy: Draining Reproductivity}

Perhaps most striking is how the Chinese government is violating the Genocide Convention's Article 2(d) through measures to prevent the children of Uyghur and other Turkic women from being born. Women have been the target of these policies for many years. Newer policies not only include previous measures such as sterilization and enforced abortions under the Chinese family planning policy, but also mass rape and sexual torture in the new concentration camp system built from 2017 onward; state-sponsored inter-racial forced marriages of Uyghur women to Han Chinese men, as well as the state placing Han Chinese male cadres (Party and government staff) in an innumerable Uyghur homes, violating the privacy of Uyghur women. Forced labor camps and factories also segregate Uyghur women and men in different places, thus serving the same purpose. All of these are acts of genocide which meet the Convention's definition under article 2(b) and 2(d). 4

Direct measures imposed by the Chinese government to restrict the number of births in the Uyghur population has a long history. It is thus not surprising that numerous new eyewitness accounts of forced sterilization have surfaced, and a new birth control policy has been imposed on Uyghur women. ${ }^{5}$ Currently, every married Uyghur woman who lives in East Turkistan and who has had no child or only one child has directly experienced either forced IUD insertion or sterilization.

Uyghur women who evade these rules and have more than two children, which is the maximum number allowed, are punished heavily. 6 Since 2017, this practice has intensifiedeven though it was relaxed for the Han Chinese. According to the leaked Karakash List, having illegal children is the most common reason for the detention of Uyghur women in Karakash county. ${ }^{7}$

3 Chris Buckley, "Brushing Off Criticism, China's Xi Calls Policies in Xinjiang 'Totally Correct,'” The New York Times, September 26, 2020, accessed September 26, 2020, https://www.nytimes.com/2020/09/26/world/asia/xi-jinpingchina-xinjiang.html.

4 United Nations (UN), General Assembly Resolution 260, Convention on the Prevention and Punishment of the Crime of Genocide, December 9, 1948 (UN Doc. A/RES/260(III)).

5 Uyghur Research Institute, Genocide in East Turkistan (Ankara: Uyghur Research Institute, February 2019), 34, accessed May 19, 2020, https://www.uysi.org/en/?p=774; Gulchehra Hoja, "Female Detainees at Xinjiang Internment Camps Face Sterilization, Sexual Abuse: Camp Survivor," Radio Free Asia, October 30, 2019, accessed May 23, 2020, https:// www.rfa.org/english/news/uyghur/abuse-10302019142433.html; Peter Stubley, "Muslim Women 'Sterilised' In China Detention Camps, Say Former Detainees," The Independent, August 12, 2019, accessed May 23, 2020, https://www.independent.co.uk/news/world/asia/uighur-muslim-china-sterilisation-women-internmentcamps-xinjiang-a9054641.html; Amie Ferris-Rotman, Aigerim Toleukhan, Emily Rauhala, and Anna Fifield, "China Accused of Genocide Over Forced Abortions of Uighur Muslim Women as Escapees Reveal Widespread Sexual Torture," The Independent, October 6, 2019, accessed May 23, 2019, https://www.independent.co.uk/news/world/ asia/china-uighur-muslim-women-abortions-sexual-abuse-genocide-a9144721.html.

${ }^{6}$ Kelbinur Tursun (victim, currently residing in Turkey), video interview with author, January 17, 2019. Additional excerpts: "China implemented forced sterilization on Uyghur women to prevent births. I, myself, had five children hidden from Chinese forces; 3 of them are illegal if they find out. To save my 6th baby, I escaped to Turkey in 2016 with my youngest child. The Chinese government arrested my husband and sentenced him to 10 years after I escaped, just because we didn't kill our babies. Despite my parents' pleading the Chinese forces, they also took away my 4 children that I left behind. No one knows their whereabouts. Just a few days ago, I recognized my daughter Ayisha in a Douyin video that a Chinese worker posted from Hoten's orphanage camp. She was three years old when I left, and 6 years old now. My home is in Kashgar city and she is in another city's orphanage camp right now. She was separated from her siblings and sent to another city. I don't know what happened to my other kids."

${ }^{7}$ Adrian Zenz, "The Karakax List: Dissecting the Anatomy of Beijing's Internment Drive in Xinjiang," Journal of Political Risk 8, no. 2 (February 2020), accessed April 30, 2021, https://www.jpolrisk.com/karakax/. 
Uyghur women are made to undergo gynecological examinations and forced to take birth control medication, have IUDs inserted, or be sterilized, both in the concentration camps as well as outside the camps. ${ }^{8}$ Adrian Zenz's research on Chinese documents and statistical data on birth rates in 2019 reveals that 97 percent of women of child-bearing age in Kashgar and Hotan city in southern East Turkistan could not or would not get pregnant and deliver a child. ${ }^{9}$ A further new report describes the extreme drop in East Turkistan birthrates as worse than the declines during the Syrian civil war and the genocides in Rwanda and Cambodia. ${ }^{10}$

The mass sterilization of women is not limited to the southern part of East Turkistan. Qelbinur Sidik, a resident of Ürümqi, located in the northern part of East Turkistan, shared her experience of how she fell victim to the policy of so-called birth control measures with long term effectiveness. She was forced to get an IUD in April 2017. However, her doctor (who was also a friend) helped her secretly remove the device to save her life after her tubal ligation became severely infected. In April 2019, during the enforced medical check-up for all Uyghur women, she was forcibly sterilized along with many other Uyghur women in the Changliyuan clinic in Ürümqi, even though she only has one child. ${ }^{11}$ Zumret Dawut, another camp survivor, also testified that she had been forcibly sterilized along with five other women in her neighborhood clinic in Ürümqi after her third child was born illegally.12 All female camp survivors and witnesses said that every woman, including unmarried young women, in the camps experienced either heavy bleeding or completely stop menstruating after being forcibly medicated on a daily basis and injected once every two weeks with a mysterious liquid. ${ }^{13}$

Adrian Zenz's analysis of family planning statistics between spring 2017 and autumn 2018 for 12 villages and the urban district in Kok Gumbez, in Kuqa county (Aksu Prefecture) also showed that $73.5 \%$ of married Uyghur women of child-bearing age were forced to undergo IUD insertions. ${ }^{14}$ According to Zenz's research, natural population growth among Uyghurs in East Turkistan declined dramatically in the two largest Uyghur prefectures, with growth rates falling by $84 \%$ between 2015 and 2018. As he noted in his report, "for 2020, one Uyghur region set an unprecedented near-zero birth target: a mere 1.05 per mill[ion] compare[d] to 19.66 per mill[ion] in 2018." 15 Chinese state media acknowledged that the birth rate, mortality rate, and natural population growth rate in East Turkistan dropped from $22.55 \%, 7.69 \%$, and $14.86 \%$

8 Qelbinur Sidik (victim and witness, currently awaiting political asylum in The Netherlands), phone interview with author, September 3, 2020; Zumret Dawut (Chinese concentration camp survivor, currently awaiting political asylum in US), phone interview with author, September 3, 2021; Aydat (Chinese concentration camp survivorcurrently residing in Kazahkstan), phone interview with author, September 3, 2020.

9 Adrian Zenz, Sterilizations, IUDs, and Mandatory Birth Control: The CCP's Campaign to Suppress Uyghur Birthrates in Xinjiang (Washington D.C.: The Jamestown Foundation, June 2020), accessed September 4, 2020, https:// jamestown.org/product/sterilizations-iuds-and-mandatory-birth-control-the-ccps-campaign-to-suppress-uyghurbirthrates-in-xinjiang/.

${ }^{10}$ Nathan Ruser and James Leibold, Family De-Planning: The Coercive Campaign to Drive Down Indigenous Birth-Rates in Xinjiang (Australian Strategic Policy Institute (ASPI), May 12, 2021), accessed May 12, 2021, https:// www.aspi.org.au/report/family-deplanning-birthrates-xinjiang.

${ }^{11}$ Sidik, interview. First mentioned in note 8.

12 Dawut, interview. First mentioned in note 8.

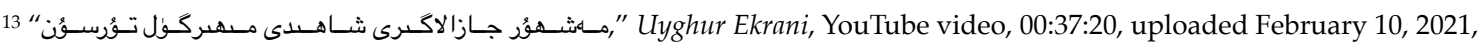
accessed March 25, 2021, https://www.youtube.com/watch?v=ijxmwpK01Fk; Afroze Fatima Zaidi, "China is Forcibly Sterilising Muslim Women in Internment Camps, According to Former Detainees," The Canary, August 17, 2019, accessed March 23, 2021, https://www.thecanary.co/global/2019/08/17/china-is-forcibly-sterilisingmuslim-women-in-internment-camps-according-to-former-detainees/; Sidik, interview; Dawut, interview; Aydat, interview; see also Gulbahar Haitiwaji and Rozenn Morgat, “'Our Souls are Dead:' How I Survived a Chinese 'ReEducation Camp' for Uighurs," The Guardian, January 12, 2021, accessed January 28, 2021, https:// www.theguardian.com/world/2021/jan/12/uighur-xinjiang-re-education-camp-china-gulbahar-haitiwaji? $\mathrm{CMP}=$ share btn tw.

${ }_{14}$ Zenz, Sterilizations, IUDs, and Mandatory Birth Control, 13.

15 Ibid., 2. 
respectively in 1978 to $10.69 \%, 4.56 \%$, and $6.13 \%$ respectively in 2018.16 Notably, both the Uyghur population's fertility rate and natural growth rate declined significantly in $2018 .{ }^{17}$

Despite the well-known consequence of draining Uyghur population, the Chinese government has persisted in applying these birth control policies against Uyghur women.

\section{State Sponsored Interracial Marriage Policy Against the Uyghur Women}

The genocidal reduction of the Uyghur population has also intensified through China's interracial marriage policy. According to China's fifth hukou (household) census statistics in East Turkistan, in 2000, interracial marriages between Han Chinese and Uyghurs made up only $1.05 \%$ of all marriages. ${ }^{18}$ China has not published any further interracial marriage statistics, but based on social media news and Chinese government news and documents, we estimate that interracial marriages between Uyghurs and Han Chinese have increased dramatically since 2017. Further, the majority of these marriages are between Han Chinese men and Uyghur women, and are very rarely the other way around. Under the prevalent patriarchal system, these women will become mothers of Han Chinese children, not Uyghur; so, as a policy, these promoted marriages further accelerate the intended destruction of the Uyghur people "as such" (as expressed in the Genocide Convention).

The Chinese government has used many incentives to promote these interracial marriage policy objectives. In August 2014, China announced a reward of 10,000 yuan annually for five years to newly married Han Chinese-Uyghur couples. They also announced a 3,000 yuan reward if the couples' children enter vocational school, a 5,000 yuan reward if their children enter university, and an extra 15 marks added to their children's university exam. ${ }^{19}$

In 2014, the Chinese government increased the reward encouraging Han Chinese men to emigrate to East Turkistan and marry Muslim women to 3.33 hectares of land and a 70,000 yuan (estimated USD \$10,847) bonus. ${ }^{20}$ Even with such incentives, interracial marriages are still not common in East Turkistan. However, beginning in 2017, following China's incarceration of millions of Uyghurs in concentration camps (and especially Uyghur men), there was a dramatic increase in the number of social media posts and Chinese state media news reports about interracial marriages between Han Chinese men and Uyghur women. Based on social media comments, Uyghur women and their entire families have been threatened with the heavy punishment of concentration camp internment if they refuse to marry Han Chinese men.

${ }^{16}$ Li Shao Xia, "An Analysis Report on Population Change in Xinjiang," Global Times, January 7, 2021, accessed February 24, 2021, https:// www.globaltimes.cn/page/202101/1212073.shtml.

17 Ibid.

${ }^{18}$ Li Shao Xia 李绍霞, “Xīnjiāng zú jì tōnghūn de diàochá yǔ fēnxī: 新疆族际通婚的调查与分析” [Investigation and Analysis of Cross-Ethnic Intermarriage in Xinjiang], Creaders.net (blog), May 9, 2014, accessed May 23, 2020, http://blog.creaders.net/u/3328/201405/181046.html.

${ }^{19}$ Huang Anwei 黄安伟, “Xīnjiāng gǔlì mín hàn tōnghūn míhé mínzú máodùn: 新疆鼓励民汉通婚弥合民族矛盾” [Xinjiang Encourages Marriage between the Han and Uyghurs to Bridge Ethnic Conflicts], New York Times, September 3, 2014, accessed May 23, 2020, https:/ / cn.nytimes.com/china/20140903/c03xinjiang/.

${ }^{20}$ Liu Minghuan 刘明焕, “Xīnjiāng kuòdà hànhuà zhèngcè hànrén qǔ jiāng nŭ kě dé 50 mǔ tián jí 7 wàn yuán xiànjīn: 新 疆扩大汉化政策 汉人娶疆女可得50亩田及7万元现金” [Xinjiang Expands Sinocization: Han People Marry Xinjiang Women Get 50 Mu Fields And 70,000 Yuan In Cash], New Tang Dynasty Television: 新唐电视台, October 30, 2019, accessed May 24 2020, https:/ / www.ntdtv.com/gb/2019/10/30/a102696368.html. 


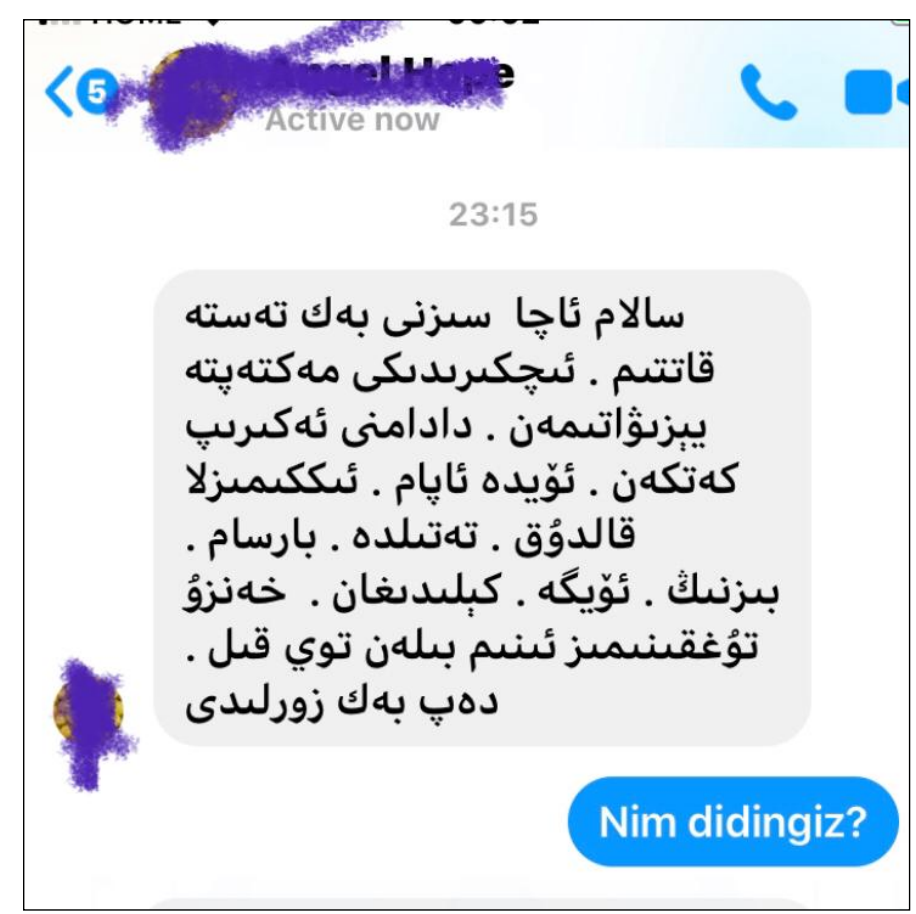

Image 1 . Screenshot 1 , image courtesy of the author.

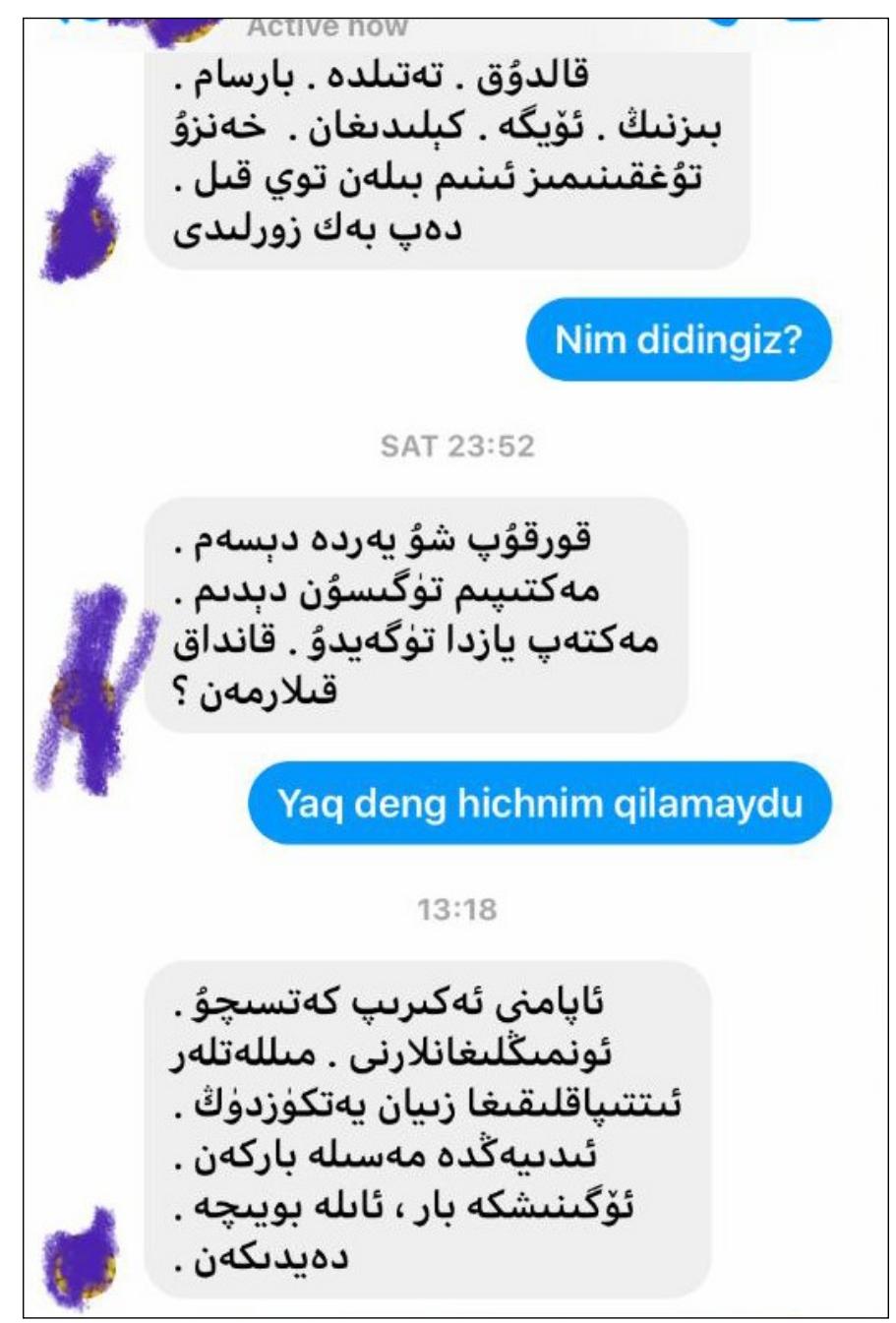

Image 2. Screenshot 2, image courtesy of the author. 


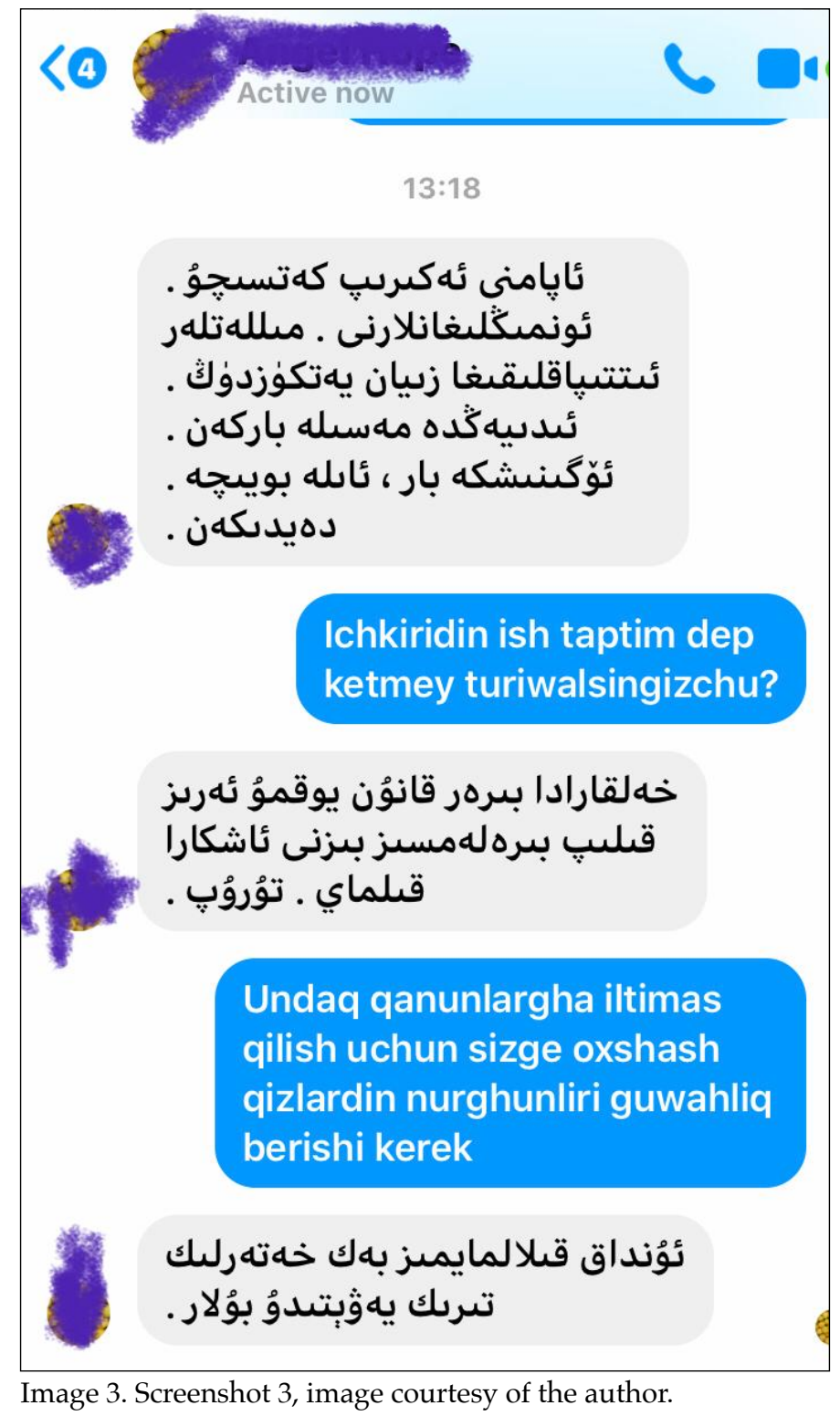

Annotated screen shots show communications with a Uyghur female student in Beijing, whose first name is Menzire. The author's translation is as follows:

Screen shot 1:

A: Salam, it is so hard for me to add you. I am writing from school in inland China. My dad was taken. And my mom [was] left at home. When I [came] back home for vacation, our Chinese "relatives" came and kept asking me to marry his brother.

R: What did you say?

Screen shot 2:

R: What did you say? 
A: I was scared. I told him that I needed to finish school. School will finish this summer. What should I do?

R: Say no, he can't do anything.

Screen shot 3:

A: What if they take my mom, too? They will say I [am] harm[ing] the ethnic unity,..an ideological problem. They may ask the whole family to go for re-education.

R: What if you tell them that you found a job and do not want to return home?

A: Is there any international law that you can use to help me without revealing my name?

R: We might need the help of a lot of girls testifying, to do that.

A: That is too dangerous, they will eat me alive if I do that.

Local Chinese work units and social security workers support Han Chinese men and often attempt to convince Uyghur women to marry these men even if the women refuse to do so of their own volition. ${ }^{21}$ It is not possible to determine the prevalence of such marriages as China conceals national interracial marriage statistics. However, the question is, if these interracial marriages are voluntary and not state-sponsored rape, then why has there been such a dramatic increase in interracial marriage between Han Chinese men and Uyghur women since 2017 when between one to three million Uyghurs were forced into concentration camps? We know that more men than women have been sent to these concentration camps, and many women may have no choice but to marry Han Chinese men when there are no Uyghur men left to marry.

The most convincing reason could be fear of being sent to one of these camps. Hundreds of Uyghur women report having married Han Chinese men in TikTok videos, on the Chinese social media platform WeChat, and on other apps, as well as in news reports seen on Chinese government websites, all of which suggests this has become a shocking and devastating new reality for the Uyghurs. ${ }^{22}$ In one of the Tik Tok videos, an Uyghur woman from Yarkand said:

We do not love each other. I married a Chinese guy to get my brother released from a concentration camp. My brother had been arrested because he had failed to participate once in a flag-raising ceremony. He was released after I married the Chinese guy but he had been mentally harmed and disabled. And my husband married me to get government money. Now

\footnotetext{
${ }^{21}$ Darren Byler, "Uyghur Love in a Time of Interethnic Marriage," SupChina, August 7, 2019, accessed May 24, 2020, https:/ / supchina.com/2019/08/07/uyghur-love-in-a-time-of-interethnic-marriage/.

22 “Xinjiang guniang wei sha bu neng tong hanzu nanzi jiehun: 新疆姑娘, 为啥不能同汉族男子结婚? 来听下当地人怎么 说” [Why Uyghur Women Cannot Marry Han Chinese], QQ Video News, November 27, 2019, accessed May 21, 2020, https://v.qq.com/x/page/f3026lh9hej.html.
} 
we have a child, but he has a Chinese lover. He hates me and always hits my head. 23

In practice, as seen in both Uyghur and Chinese patrilineal culture, forcing women to marry Han Chinese men means their future children will not belong to their mothers' ethnic group. This represents one more measure intended to prevent Uyghur children from being born and reducing the Uyghur population as a result. Further, we believe the colonial ideology of the Chinese government entails the belief that their domination of women means to not only dominate the land but also the entire colonized people (more on this below). This could explain why there are very few interracial marriages between Uyghur men and Han Chinese women, and most Chinese government and social propaganda targets Uyghur women rather than men.

To disguise their state-sponsored forced marriage policy, the Chinese government also established dating services around various East Turkistan cities. The sole function of these services is to find Uyghur women for Han Chinese men. All of these dating services are intrinsically political, as they are linked directly to, and guided by the Chinese government. One of their video advertisements in Kashgar city, published in Uyghur and translated below, is another example of how the Chinese government treats Uyghur women as commodities-it refers explicitly to government policy and includes an implicit threat:

Thank you to the party and the government! In order to support our government's policy of increase Uyghur and Han Chinese marriage, we need 100 Uyghur women urgently! It is important for the ethnic unity between the Uyghur and the Han Chinese! Please call us and get counseling. Anyone is welcome to introduce friends and family members. Contact number: $17699989766 .{ }^{24}$

As a result, the privilege and advantage of freely obtaining Uyghur women, as a wife and as a commodity, give Han Chinese men an ideologically framed image through which to view Uyghur women and, particularly how to use and value them.

Several other videos found by Uyghur activists on Chinese social media show how Chinese men try to attract Han Chinese settlers to the region. These videos contain phrases such as: "Do you want Uyghur beauties? Come, I'll arrange it for you tonight," and "Do you want to marry Uyghur girls? They can eat pork. They could not eat it before, but they can eat it now. Don't worry about [the] cultural differences." 25 These videos include both governmentsponsored propaganda videos as well as videos distributed by Han Chinese individuals. This is often accompanied by a stream of insults, used as a tool to humiliate, destroy, and assert power over the Uyghurs.

${ }^{23}$ Zumrat Dawut, "Conversation of Uyghur Women who are Married to Han Chinese in Tik Tok Video," Facebook, November 13, 2020, 2:38 p.m., accessed, May 18, 2021, https://www.facebook.com/100034398679054/posts/ $\underline{397615751395044 / ? \mathrm{~d}=\mathrm{n}}$.

${ }^{24}$ Ashimu Kashijalian 阿西姆·卡什加里安, “Zhongguo shipin guanggao huyu baiming Weiwuer nuxing kuai jia Hanren: 中国视频广告呼吁百名维吾尔女性快嫁汉人” [Chinese Video Advertisement Urgently Need 100 Uyghur Women to Marry Han Chinese Men], Voice of America, August 22, 2020, accessed August 22, 2020, https:// www.voachinese.com/a/china-xinjiang-inter-marriage-20200821/5553607.html.

${ }^{25}$ Doam (@doamuslims), “Chinese Official Interrogates Uyghur Muslim Girl,” Twitter, April 2, 2019, 12:02 p.m., accessed May 15, 2021, https://twitter.com/doamuslims/status/1113109430177075200; Arslan Hidayat (@arslan-hidayat), "Uyghur Girl Publicly Pimped," Twitter, May 13, 2020, 8:06 p.m., accessed May 15, 2021, https://twitter.com/ arslan hidayat/status/1260723117682561025. 
Slavery of Uyghur Women in China's Forced Labor Camps

Since 2006, the Chinese government has forced every Uyghur household to send one person to perform factory work in inland China, as shengyu laodong (excess labor force). ${ }^{26}$ This policy has been intensified since 2017, under the guise of a new so-called "poverty alleviation" policy. Three important characteristics are concealed within this policy:

- Mainly young Uyghur women are recruited for factory work outside of East Turkistan and are thus separated from the male population of their own people.

- All the workers are forcibly sent away to inland China, with those married separated from their husbands and children.

- They live under massive surveillance with no freedom of movement or the right to return to their homeland.

China's government published a White Paper in September 2020 claiming that every year from 2014 to 2019, the average annual relocation of surplus rural labor amounted to more than 2.76 million people, of whom nearly 1.68 million-or over 60 percent-were in southern East Turkistan, which is mainly populated with Uyghurs. ${ }^{27}$ This indicates that 6.72 million Uyghurs were relocated or sent to forced labor during these four years. Even though the White Paper did not mention the gender of these workers, claiming that they were voluntary and not forced, several sources-including witness testimonies, Uyghur sources, and western media investigative reports-proved that these workers are mostly women. The proportion of male Uyghurs in prison and detention, in contrast, constitutes an overwhelming majority. Based on local Chinese government data from 2017 and 2018 analyzed by Adrian Zenz, the share of all male adults in concentration camps in the document sample was 9.2 times higher than arrested female adults, ${ }^{28}$ which could explain why the number of Uyghur women is much higher in forced labor.

The Uyghur women sent to factories across inland China could well be providing services to global companies such as Volkswagen, Dell, General Motors, Cisco, Calvin Klein, among others. According to a March 2020 Australian Strategic Policy Institute report, at least 80,000 Uyghurs, mostly women, have been transferred;29 the women are either sent directly from Uyghur cities and villages, or by way of the concentration camps. They are not allowed to return home when they get sick even if they have finished their job contract. ${ }^{30}$ One factory manager in Shandong Province told Bitter Winter magazine that Uyghurs must work for one year before they are eligible to go home to visit relatives. Even if family members die, they cannot go home without permission. For those who have worked for more than one year and were fortunate enough to be granted permission to go home to visit relatives, if do not come

26 Uyghur Human Rights Project, China: Transfer of 400,000 Young Uyghur Women into Eastern China (Brussels: Human Rights Without Frontiers International, June 19, 2008), accessed September 21, 2020, http://www.davidkilgour.com/2008/Jun 202008 01.htm.

27 The State Council Information Office of the People's Republic of China, Employment and Labor Rights in Xinjiang, (white paper, The People's Republic of China, September 17, 2020), accessed January 28, 2021, http:// english.www.gov.cn/archive/whitepaper/202009/17/ content WS5f62cef6c6d0f7257693c192.html.

28 Adrian Zenz, “'Wash Brains, Cleanse Hearts:' Evidence from Chinese Government Documents about the Nature and Extent of Xinjiang's Extrajudicial Internment Campaign," Journal of Political Risk 7, no. 11 (November 2019), accessed May 15, 2021, https:/ / www.jpolrisk.com/wash-brains-cleanse-hearts/.

29 Vicky Xiuzhong Xu et al., Uyghurs For Sale: "Re-Education," Forced Labour, and Surveillance Beyond Xinjiang (Australian Strategic Policy Institute, March 1, 2020), accessed May 23, 2020, https:// www.aspi.org.au/report/uyghurs-sale.

30 Li Mingxuan 李明轩, “Dàpī xīnjiāng wéizú rén bèi qiángzhì sòng wăng nèidì gōngchăng wàichū xū dài dìngwèi shǒu huán: 大批新疆維族人被強制送往內地工廠外出須戴定位手環” [A Large Number of Uyghurs in Xinjiang were Forcibly Sent to Mainland Factories, Wearing Tracking Bracelets], Bitter Winter, March 9, 2020, accessed May 25, 2020, https:// zh.bitterwinter.org/new-re-education-of-uyghurs-forced-labor-outside-xinjiang/. 
back within the stipulated time, they are forcibly returned and punished. If they do not come back, they will be put in an education transformation camp, or prison. ${ }^{31}$

"I was detained in a concentration camp for two years and it is one year now that I am in a labor camp. It is ok if they don't pay me, but I am happy if they allow me to see my children once in a while. I can do everything they want, but my kids are in a boarding school and I couldn't see them when I came home," explained Aydin, who finally received permission to visit her own home for the first time after three years. She revealed this information to her friend overseas in a secret video conversation, in which she displayed the police tracking bracelet on her arm. For her safety, we decided to publish the photo of the bracelet, but not the video.

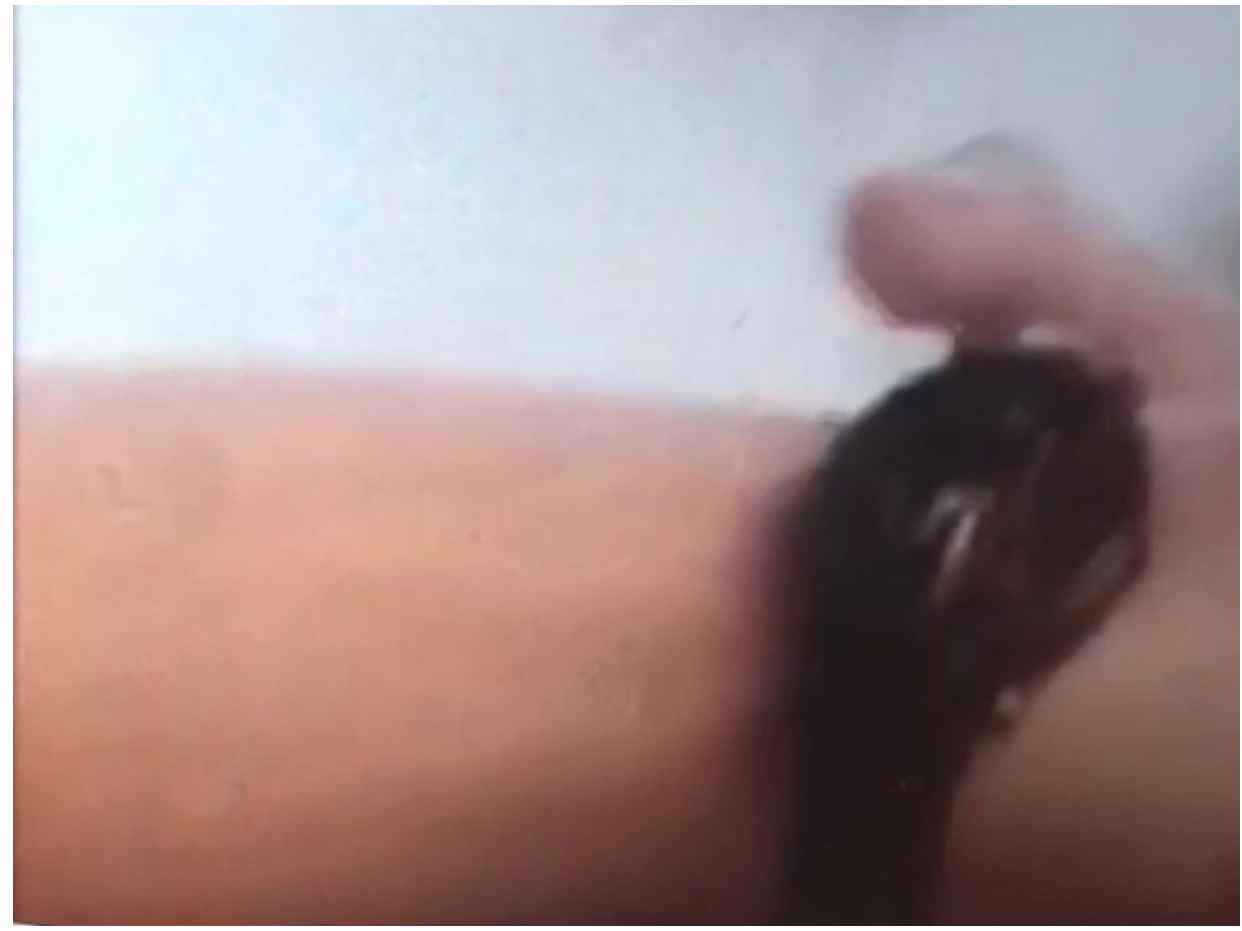

Image 4. Tracking bracelet used to control forced labor workers, image courtesy of the author.

Many educated women are also sent to low-skill slave labor camps and separated from their children and homes. Dilnur Idris, an Uyghur nurse, on her release from a concentration camp in May 2019, was sent to a slave labor textile factory to do unpaid low-skill heavy work. She sent a brave message to her sister Gulnur Idris in Melbourne, saying: "I may never have a chance to get out, or contact you again. Please stand up for me!"32

A young ethnic Kazakh man, Yelisin Erkin, who did administration work in Ghulja City's Chapchal forced labor camp in East Turkistan in 2015 testified about how the women were forced to work in these camps.

70 percent of the workers are women between 16-45 years old working in the factory designated as a forced labor camp in Chapsal County. These women are never allowed to go home and see their children, husbands, or other family members unless they have emergency issues, and get permission from

\footnotetext{
${ }^{31}$ Ibid.

32 ABC News In-Depth, "How China is Creating the World's Largest Prison: Four Corners," YouTube video, 00:36:3900:38:30, uploaded on July 16, 2019, accessed May 15, 2021, https:/ / m.youtube.com/ watch?feature=youtu.be\&v=taxd1Ht 18.
} 
the factory owner. Monthly salaries range between $\$ 5.88$ to $\$ 61.90$ - barely enough for their hygiene expenses-despite being forced to work 14 hours every day. ${ }^{33}$

An unpublished video secretly taken in the White Rose factory in Tianjin 13 years ago and preserved by the author also revealed similar evidence. This video explains how Uyghur women aged 16-24 are forced to go to inland China for unpaid factory work. "If we refuse, we have to pay a fine of 3000-5000 yuan, and they will destroy our houses with a bulldozer," said the women in the video. ${ }^{34}$

A group of young Uyghur women who had been forced to come to work at a telephone company in Hubei province in central China in the first quarter of 2019 said the following to her cousin in Europe over the telephone in 2021. She disappeared the next day and her cousin not been able to contact her again.

They said we could go back home when they bring new workers. When I arrived, they chose some women from among the previous workers, and the government decided these women could return home. After these women left, we never heard about them. We don't know where they [have] sent them. Please help me! They have selected several of us today. I am amongst them. I was separated from my baby daughter three years ago. I don't know where she is right now. I don't know where they will take us tomorrow. Please help!35

Not Only Mass Gang Rapes but Sexual Torture

Similar to the genocides in Bosnia, Rwanda, and Darfur, Uyghur and other Turkic women have been targeted through mass rape as a tool of genocide, which Chinese state policy facilitates through the newly built women's concentration and forced labor camps. A recent camp survivor, Tursunay Ziyawudun, 39, described what happened to her as follows:

I was bleeding heavily after they kicked my stomach so badly in the interrogation room. I didn't know what these dimly redlit rooms were for when I passed by, going all the way to the interrogation room. I learned later it was the rooms prepared for the rape and torture of detainees. ${ }^{36}$

She, herself, was gang-raped, sexually tortured, and mutilated when she was taken to those dark rooms.

There were 12 women in my cell, each one of them, mostly young girls and aged under 40, randomly taken out at night. When they came back, they looked as if their spirit had vanished. I didn't imagine sexual torture and rape until they took me there. I thought those women who were taken out at night were taken for interrogation and physically tortured. ${ }^{37}$

\footnotetext{
33 Yelisin Erkin (eye-witness, currently awaiting political asylum in Ukraine), phone interview with author, January 25, 2021.

${ }^{34}$ Quote was from a private video, provided by East Turkistan Information Center. This video is not published publicly to protect the identities of the forced labor workers in the video.

${ }^{35} \mathrm{Ibrahim}^{*}+$ (Second-hand witness), interview with author, March 28, 2021.

36 Tursunay Ziyawudun (Chinese concentration camp survivor), phone interview with author, March 25, 2021.

37 Ibid.
} 
Another camp survivor, Gulbahar Jelilova, told the author: "The young Chinese guy sexually assaulted me in the interrogation room. I begged him: 'Don't you have a mother?' He banged my head to the table and said: 'Don't you dare compare yourself to my mom! You are not human to me! You cannot compare yourself to any human!'"38 Both Gulbahar Jelilova and camp survivor, Zumret Dawut, confirmed the use of gang rape in concentration camps. ${ }^{39}$ Tursunay Ziyawudun added:

Each time, the same tall Chinese man with a blue suit and shining shoes came with his other followers with military camouflage uniforms. They talked to each other. From their accents, I learned they are Han Chinese. (...) I heard one of these Chinese men say: 'She is going to die. She is bleeding too much!' when they inserted an electric baton in my private parts and tortured me, like pulling all of my organs one by one, chopping my body into a thousand pieces. Another one said: 'So what?!' The third man said: 'No difference! Just destroy her womb!' I didn't get it why they hate women's wombs.40

The masked men who raped and sexually tortured her were likely Chinese government officials and soldiers who represent the Chinese state.

Like many other detainees, Tursunay did not know what her crime was when she was arrested. "When they brought me to the concentration camps from the detention center, they gave me a list of papers and forced me to choose one of the crimes they listed," she said. She shared what she remembered from the list as follows:

1. wearing a long dress;

2. wearing a hijab [head scarf/head covering];

3. shaved body hair;

4. praying;

5. having a Muslim name;

6. traveled abroad;

7. participated in a religious nikah [Muslim wedding] ceremony

8. having a traditional handheld vessel at home that contains water to assist in bathroom hygiene;

9. having a religious friend;

10. your father is an Imam [Islamic religious leader];

11. participated in a party and there was a religious person at the party;

12. contacted someone overseas by phone;

13. having an illegal child outside of the government plan. ${ }^{41}$

"They had a long list; I don't remember all," she said. "I chose the one that said 'traveled abroad,' because my husband was a Kazakhstan national and I went to Kazakhstan before. Many people do not even fit into the list; they didn't have any fault[s], but they have to choose." 42

\footnotetext{
${ }^{38}$ Gulbahar Jelilova, phone interview with author, March 24, 2021.

${ }^{39}$ Dawut, interview.

${ }^{40}$ Ziyawudun, interview, March 25, 2021. First mentioned in note 36.

${ }^{41}$ Ibid.

42 Ibid.
} 
Tursunay had surgery in the United States after being released due to the activism of her Kazakh husband and diplomatic pressure on China from Kazakhstan. Doctors removed her badly injured uterus due to severe medical risks. She cannot be a mother anymore, but she said the surgery helped her since she feels like she removed something scary and dirty from her life. "They will make you hate to be a women," she said. "I feel a little better and feel safe after doctors removed my womb in the US, because it is something that reminds me, every second, of those horrible and disgusting days." 43

The ICTR noted that "[r]ape and sexual violence also constitute genocide in the same way as any other act, as long as they were committed with intent to destroy a particular group targeted as such." 44 The tribunal also concluded rape and sexual violence were one of the worst ways of inflicting physical and mental harm on women. ${ }^{45}$ Clearly, the Chinese government's actions constitute a serious violation of Article 2(b) of the Genocide Convention.

In many cases, systematic mass rape in China's concentration camps is intentional, conducted from the top-down, and centrally directed as part of the genocide plan to destroy the Uyghur people and nation. China's intention to destroy the whole Uyghur people and nation by destroying Uyghur women and their dignity is evident through the horrific torture and systematic mass rape in Chinese concentration camps, as confirmed by several victims and eyewitnesses. ${ }^{46}$

\section{'Pair Up and Become Family' Policy: Invaders in the Uyghur family}

The Chinese government's policy of specifically targeting Uyghur and other ethnic Muslims in East Turkistan is done through several means, including with experimental AI technology, observing each person's movements with digital spying techniques such as face and voice recognition cameras and phone spyware, collecting blood types and DNA samples from entire segments of the Uyghur population, as well as sending more than one million Han Chinese male cadres into Uyghur homes, as human spies, to sleep over for one or two weeks every month, monitoring household members for possible infractions. All of these tactics induce responses ranging from anxiety to outright terror, severely damaging the Uyghurs' mental health. ${ }^{47}$ Uyghur women have been particularly targeted as a vulnerable victim of this policy.

In many Uyghur families, Han Chinese men dominate the Uyghur women they are paired up with them while male Uyghur household members have been detained elsewhere. Many instances of sexual harassment and rape have been reported during these male Han Chinese sleepovers with Uyghur Muslim families. ${ }^{48}$ Zumret Dawut, who was finally able to escape to the United States, stated:

\footnotetext{
${ }^{43}$ Ibid.
}

44 United Nations, "Rwanda International Criminal Tribunal Pronounces Guilty Verdict in Historic Genocide Trial," press release, September 2, 1998, accessed May 15, 2021, https://www.un.org/press/en/ 1998/19980902.afr94.html.

${ }^{45}$ See in particular the article abstract in Jonathan M. H. Short, "Sexual Violence as Genocide: The Developing Law of the International Criminal Tribunals and the International Criminal Court," Michigan Journal of Race and Law 8, no. 2 (2003), accessed May 15, 2021, https:/ / repository.law.umich.edu/mjrl/vol8/iss2/5.

46 Matthew Hill et al., “'Their Goal is to Destroy Everyone:' Uighur Camp Detainees Allege Systematic Rape,” BBC News, February 2, 2021, accessed February 4, 2021, https://www.bbc.com/news/world-asia-china-55794071; Sayragul Sauytbay and Alexandra Cavelius, The Chief Witness: Escape from China's Modern-Day Concentration Camps, trans. Caroline Waight (Melbourne: Scribe, 2021).

${ }^{47}$ Alexandra Ma, "China is Reportedly Sending Men to Sleep in the Same Beds as Uighur Muslim Women while their Husbands are in Prison Camps," Business Insider, November 4, 2019, accessed May 23, 2020, https:// www.businessinsider.com/china-uighur-monitor-home-shared-bed-report-2019-11.

48 Peter Goff, “'Become Family:' China Sends Officials to Stay with Xinjiang Minorities," The Irish Times, December 17, 2019, accessed May 25, 2020, https:/ / www.irishtimes.com/news/world/asia-pacific/become-family-china-sendsofficials-to-stay-with-xinjiang-minorities-1.4118327. 
Government workers appoint those Han Chinese to sleep over in every Uyghur household, under the program of 'Pair Up and Become Family.' They do not care if there are any men in the household or not, an extra bed or not. They do not allow us to ask any personal information about those Chinese guests. We do not know what kind of people they are or their medical or social or criminal history. 49

Qelbinur Sidik, who recently found refuge in the Netherlands, said: "I was threatened, intimidated, and attacked with verbal sexual harassment in front of my husband many times in my own home by the Han Chinese sleepover men. Even though I am free right now, I constantly suffer from nightmares, and anger issues." 50

Zumret Dawut also described how a 20-year-old single Han Chinese male "relative" of her 12-year-old daughter, matched by the Chinese government, became a huge problem for her before she was eventually able to leave for Pakistan with her family. "Bring your daughter to sleepover in my home. Make sure she takes a shower before she comes," she remembered her daughter's male "relatives" asking every weekend. "I found excuses to delay the time and left the country with my daughter, but the rest of the Uyghur mothers have no chance to escape like me." 51

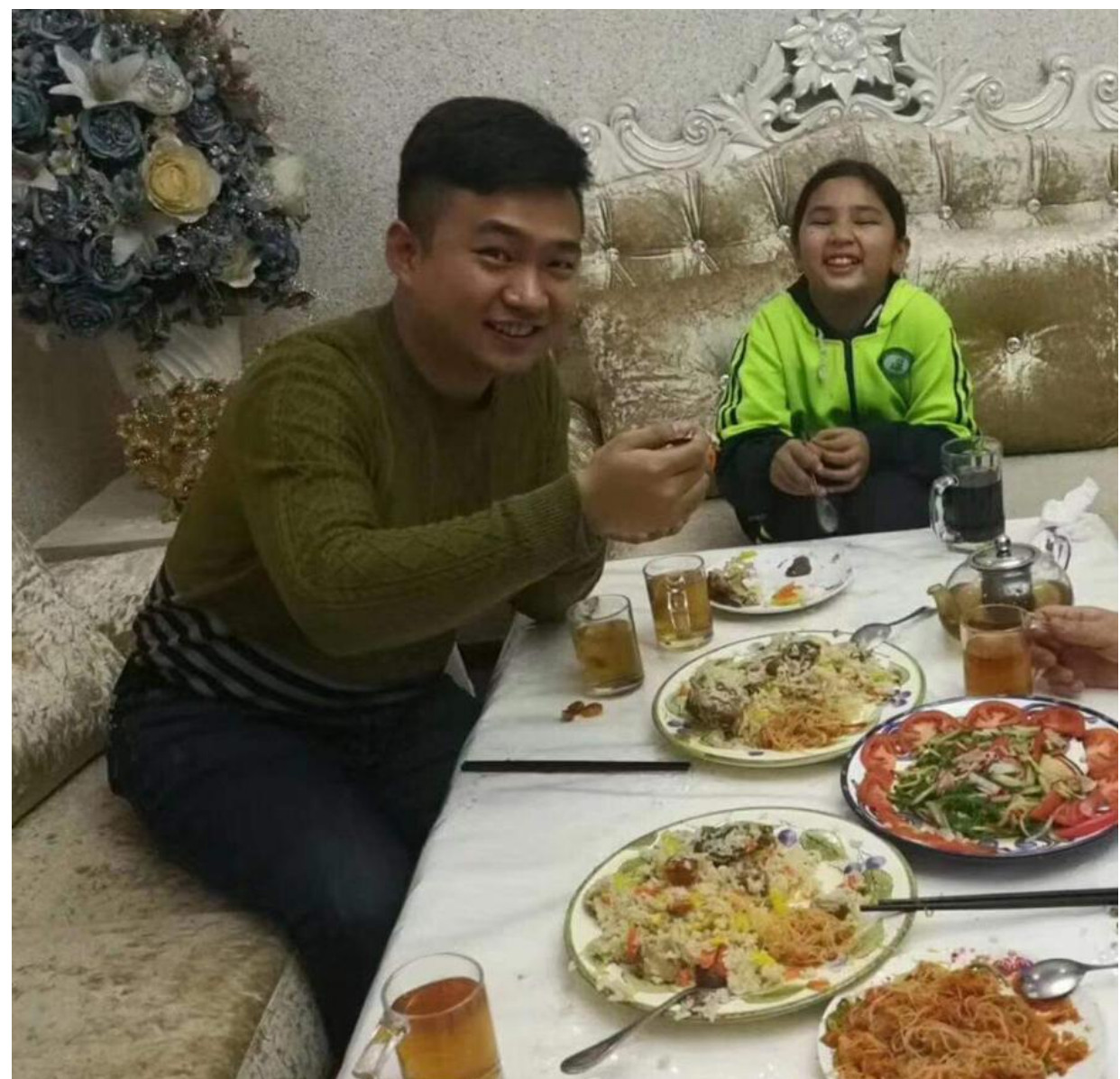

Image 5. The Chinese government appointed Han Chinese male "relative" for Zumret Dawut's 12-year-old daughter, image courtesy of the author.

\footnotetext{
${ }^{49}$ Dawut, interview, March 24, 2021.

50 Sidik, interview, September 3, 2020.

${ }^{51}$ Dawut, interview, March 24, 2021.
} 
The colonial ideology behind the Pair Up and Become Family policy created an opportunity for Han Chinese settlers to dominate Uyghur women as colonial property. There are many cases of Han Chinese men raping and assaulting Uyghur women, which the first author learned about from unofficial Uyghur sources about Han Chinese men. However, we could not include these cases here since it is very difficult to verify each one, and many of the victims are still in East Turkistan.

\section{China's Genocidal Policy Ideas: Where did they Originate?}

Where do these genocidal policy ideas and the motivating intention come from? As Maureen Hiebert noted in her book Constructing Genocide and Mass Violence, the "idea of destroying the group starts with a cluster of social and political attitudes, belief, values and practices." 52 This is also very true in the case of China's genocide.

The General Secretary of the Chinese Communist Party, Xi Jinping, is singularly preoccupied with the "rejuvenation of the Great Chinese Nation," and noted in his report to his party's 19th national congress that: "We should do more to foster a Chinese spirit, Chinese values, and Chinese strength, to provide moral guidance to our people." 53 This implies there is no survival space for other ideological values. As a result, any Uyghurs or others in the East Turkistan colony who do not succumb to the forced transformation into ethnic Han Chinese will be considered a threat-an "ideological enemy," and as "opponents" that must be eliminated. The idea of the superiority of the Han Chinese belief system that can dominate, absorb, and eliminate any other group is applied as a first step, particularly with the conception of a superior self vs. an inferior other which many Han Chinese settlers have cultivated towards the Turkic peoples in the colony. Once the belief of an enemy is created and established, the intent to eliminate soon follows. In this regard, briefly addressing the colonial history of East Turkistan is significant in this article as women are the symbol of the land, country, honor, and dignity of the Uyghur and other Turkic Muslims culture, who their Chinese colonizers subject to the most direct and symbolic destruction.

\section{Brief History of Colonization of East Turkistan}

East Turkistan has natural boundaries as well as a constructed border formed by the Great Wall. In the past, before the Mongol and Manchu invasions, Uyghurs established their own kingdoms and states, such as the former Ediqut Uyghur state and the Qarahanli state..$^{44}$ Today, the Chinese government claims that East Turkistan was part of its former Han dynasty's empire. However, this claim is unfounded; the Han dynasty only captured the Turpan area-a minute portion of the vast Tarim and Jungaria regions of East Turkistan - for a short period in 120 BCE. The Han Chinese state was never able to rule East Turkistan until after 1949.55

In 1949, when the new Chinese nation state was established, it claimed the previously colonized borderland territories of the Manchu empire, including East Turkistan, Mongolia, and Tibet. Globally, this was a period of decolonization, and the people of East Turkistan had already established the East Turkistan Republic after the Manchu empire collapsed. ${ }^{56}$ Undeterred, the newly established Chinese state claimed East Turkistan as Chinese state territory, which was illegitimate and should be regarded as an invasion. Nonetheless, the newly formed UN officially recognized China's territorial claim. Despite this victory, Chinese

\footnotetext{
52 Maureen S. Hiebert, Constructing Genocide and Mass Violence: Society, Crisis, Identity (London: Routledge, 2017), 23.

53 Xi Jinping, "Secure a Decisive Victory in Building a Moderately Prosperous Society in All Respects and Strive for the Great Success of Socialism with Chinese Characteristics for a New Era" (speech, Beijing, delivered at the 19th National Congress of the Communist Party of China, October 18, 2017), accessed September 23, 2020, www.xinhuanet.com/english/download/Xi Jinping's report at 19th CPC National Congress.pdf.

54 James A. Millward, Eurasian Crossroads: A History of Xinjiang, 1st ed. (New York: Columbia University Press, 2007), 52.

55 Ibid., 24.

56 Gardner Bovingdon, The Uyghurs: Strangers in Their Own Land, 1st ed. (New York: Columbia University Press, 2019), 31-39; Rian Thum, The Sacred Routes of Uyghur History (Boston: Harvard University Press, 2014), 4.
} 
government officials continued to grow uneasy; because the religion, culture, and ethnicity of East Turkistan's population are highly distinct from those of the Han Chinese, the assimilation of Uyghur and other Turkish people would still be difficult to accomplish. Beijing increasingly felt that they had failed to assimilate Uyghurs and other Turkic Muslims. Further, since its recent rise to power, China has aimed to expand, through central Asia and Europe, to implement its New Silk Road project (or "One Belt, One Road," OBOR) to create economic connections between more than 65 countries. This has rendered East Turkistan even more geostrategically significant as the region is pivotal in China's ability and capacity to accomplish such a project. ${ }^{57}$ The characteristics of both China's military and civilian-settler colonialism of East Turkistan have also determined China's intention to destroy the Uyghurs and other Turkic Muslims, as the Chinese government has come to view the local population as an obstacle.

\section{China's Ideological Tools of Genocide: Punishment in Legalism}

China's intention of genocide today stems from its recent colonialist efforts in East Turkistan. In the implementation of the genocide, the state mobilizes the legalist concept of punishment first pioneered in Qin dynasty. Ancient Chinese Legalism was originally developed to harshly control and exploit people under state rule, but it has now become one of the tools of genocide in its application on China's colonized region of East Turkistan. In the following sections, we discuss how the ancient idea of punishment, as seen in legalist thinking, is applied to Uyghur women as a tool of genocide in recently colonized East Turkistan.

The head of the Chinese state, Xi Jinping, was quoted in a leaked secret speech as saying that there should be "absolutely no mercy" toward the Uyghurs. ${ }^{58}$ This clearly indicates the intent to target the Uyghurs and other ethnic Muslims in East Turkistan, portraying them as a deadly threat that must be eliminated if China is to build its new empire. This intention also aligns with the classic Chinese philosophy of Legalism (Fa Jia) that emerged during the Warring States period. The main ideas of Legalism focus on about power and position, as well as how to ignore moral issues and dominate those ruled. The famous Chinese legalist thinker and official Shang Yang argued: "If strength remains on the other side, one perishes; but if strength is removed on the other side, one attains supremacy." 59

The Chinese government has always considered the people of East Turkistan as a threat that needs to be destroyed. This follows from the zero-sum thinking in legalism, formulated to help those in power to gain supremacy over any region. As one of the tools for enforcing supremacy, Legalists advocated punishments applied even to people who were innocent, much like China's cruel and punitive policies being applied to Uyghurs and Turkic Muslims today. Indeed, as detailed in the accounts of Tursunay Ziyawudun as well as others cited above, East Turkistan women are punished despite having committed no real crime (other than their identity as Uyghur women). The Book of Lord Shang described punishment as follows:

Therefore, if you govern by punishments, the people will fear; being fearful, they will not commit villainies; there being no villainies, people will be happy in what they enjoy. If, however, you teach people by righteousness, they will be lax; if they are lax, there will be disorder; if there is disorder, the people will suffer from what they dislike. 60

\footnotetext{
57 Jeff Desjardins, “Mapped: China's Most Ambitious Megaproject-The New Silk Road," Business Insider, March 19, 2018, accessed September 14, 2020, https://www.businessinsider.com/chinas-most-ambitious-megaproject-thenew-silk-road-mapped-2018-3.

58 Austin Ramzy and Chris Buckley, “'Absolutely No Mercy:' Leaked Files Expose How China Organized Mass Detentions of Muslims," The New York Times, November 16, 2019, accessed March 21, 2020, https:// www.nytimes.com/interactive/2019/11/16/world/asia/china-xinjiang-documents.html.

59 Shang Yang, The Book of Lord Shang: A Classic of the Chinese School of Law, trans. Jan Julius Lodewijk Duyvendak (London: Arthur Probsthain, 1928), 155.

60 Ibid., 65
} 
The righteousness referred to here is, of course, the Confucian idea that has helped underpin Chinese patriarchy, but which legalists saw as an obstacle to their ideology of total power. Cruel punishment methods were encouraged by legalists, such as when Shang Yang advocated heavier punishments in order to make it easier to control the people: "In applying punishments, light offences should be punished heavily; if light offences do not appear, heavy offences will not come. This is said to be abolishing penalties by means of penalties, and if penalties are abolished, affairs will succeed." 61

As we have seen, China's policies in East Turkistan today reject and grossly violate human rights and are reinforced by legalist thought. The devastating policies of sterilization and forced labor, as well as the state-sponsored forced marriages and sexual torture applied to Uyghur women as legalist-styled punishments are evidently intended for genocidal purposesto destroy the Uyghur and other Turkic Muslim people. For example, in mass rape camps, Uyghur women are sexually tortured after they are raped. Their body parts used for childbirth become the enemy of the perpetrators, since they regard Uyghur women as the vehicle of Uyghur population growth. As a result, attempts to eliminate the Uyghurs are being implemented using the barbaric punishment methods disclosed in the testimonies.

Clearly, the Chinese government's intention is not only to instill fear in people, as the legalists advocated, but also to commit genocide through legalist-style punishments applied to its colony of East Turkistan.

Umide, a 30-year-old Uyghur woman now living in the Netherlands, who traveled to Ürümqi in 2018, and, Eldos, a Kazak Canadian who traveled to Ghulja in 2019, both learned that the threatening and punishing of the male relatives of Uyghur women who refuse to marry Han Chinese men or putting the entire family of the Uyghur woman in a concentration camp is a common issue. ${ }^{62}$ Uyghur women are also punished for their lifestyles and tortured because of so-called sins of relatives, which they never committed. ${ }^{63}$ These kinds of punishments are referred to as the lianzuo or zuxing system, meaning shared responsibility and family penalty. This originates from legalism, but it has resulted in some contemporary Chinese believing that it is part of Chinese culture to put family above the individual and that an individual's sin can be the sin of the family, since an individual's achievement is also considered to honor the family. 64

Legalism stressed the related measure of the shiwu (ten-five) system of population control, with groups of five or ten families that become mutually responsible for each other (lianzuo). 65 The Book of Lord Shang stressed these extended penalties of Legalism as follows:

If there are severe penalties that extend to the whole family, people will not dare to try (to see how far they can go), and as they dare not try, no punishments will be necessary. If punishments are heavy and rigorously applied, then people will not dare to try (to see how far they can go), with the result that, in the state, there will be no people punished.66

The Book of Lord Shang further explained that the reason for making people responsible for each other was also to have them spy on each other as follows:

\footnotetext{
61 Ibid., 133.

62 Umide $^{*}+$ (eye witness), phone interview with author, March 22, 2021; Eldos ${ }^{*}+$ (eye witness), phone interview with author, January 2, 2021.

${ }^{63}$ Ziyawudun, interview, March 25, 2021. First mentioned in note 36.

64 Yao Lao, "Families that Hang Together," China Daily, May 17, 2004, accessed March 22, 2021, https:/ / www.chinadaily.com.cn/ english/doc/2004-05/17/content 331252.htm.

${ }^{65}$ Daniel Haitas, "Shang Yang and Legalist Reform in The Ancient Chinese State of Qin," Challenges of the Knowledge Society 12 (2018), 524-531, accessed March 22, 2021, https:/ / doaj.org/article/1675416918714f20b18ef6ce5890255f.

66 Shang Yang, The Book of Lord Shang, 143.
} 
Now the people in groups of five are responsible for each other's crimes, they spy on each other to discover transgressions, they denounce each other and cause hostile relations. By thus establishing enmity the people harm each other, they injure friendly feelings, destroy benevolence and kindness and damage scholarship and culture. ${ }^{67}$

This ancient method of punishing extended family members or relatives is currently widely applied to the people of East Turkistan. Abdurishit Burhan, an Uyghur witness currently living in Canada explained: "Each 10 families were made into one group and had to be responsible for each other's behavior, and spy on each other. People know what kind of torture they will receive if they are going to be arrested. Sometimes I have seen people betray their family member to save themselves." Abdurishit added that the "mutual responsibility policy started in 2013 in Kashgar." 68 This is exactly what legalism promoted:

In a condition of complete good government, husband and wife and friends cannot abandon each other's evil, cover up wrong-doing and not cause harm to relatives, nor can the men from the people mutually conceal each other from their superiors and government servants. ${ }^{69}$

According to the Uyghur witness, Umide:

Each local unit in every neighborhood has Uyghur social workers. They must report and arrest 30 persons in certain periods, for so called re-education camps. They start to report and arrest people that they have no relationship with. Later, they will arrest their relatives. One of my friends works in a local unit. They work under the strict surveillance of people's police. She said she cried and reported her cousin to fill the numbers. When there are no people left to arrest, they have to report themselves. It is a very common and well-known issue. ${ }^{70}$

The tenets of Legalism have thus become a very useful tool for the implementation of genocide in China's colony of East Turkistan. Until now, most men and those who are educated, young, and strong have already been eliminated in East Turkistan. This, too, is exactly what Legalism advocated: "To remove the strong by means of a strong people brings weakness; to remove the strong by means of a weak people brings strength."71

The rest of the population-mostly women-are controlled through forced labor as the Legalist argument also proposed, in the following way:

If compulsory labour service is rare, the people will feel safe; if the people are safe, the ministers will gain no extra power; if the ministers have no extra power, powerful and influential

\footnotetext{
67 Ibid., 35.

${ }^{68}$ Abdurishit Burhan*, in-person interview with author, March 19, 2021, Toronto, Canada.

${ }^{69}$ Shang Yang, The Book of Lord Shang, 36.

70 Umide, interview, March 22, 2021. First mentioned in note 62.

71 Shang Yang, The Book of Lord Shang, 153.
} 
men will be extinguished; and if powerful and influential men disappear, all credit will be due to the sovereign. ${ }^{72}$

\section{Conclusion}

The ICTR, dealing with another recent genocide, explained that "Genocide does not imply the actual extermination of a group in its entirety, but is understood as such, once any one of the acts mentioned in article II (2)(a) through II (2)(e) is committed with the specific intent to destroy 'in whole or in part' a national, ethnic, racial or religious group."73 The ICTR commentary also explained that: "Imposing measures intended to prevent births within the group" is prohibited under the Convention's Article 2(d) and is exemplified by the practice of sterilization, forced birth control, and separation of sexes from the targeted group. ${ }^{74}$

It is clear that the Chinese government has violated the UN Genocide Convention by way of its state policies which include conducting mass scale sterilization, separating the genders by sending Uyghurs and other Turkic Muslim males to concentration and forced labor camps, and by forcing Uyghur women to marry ethnic Han Chinese. All of these severe acts are a direct outcome of Chinese colonialism in East Turkistan and violate not only Article 2(d), by imposing measures intended to prevent births within the group, but also Article 2(b), "causing serious bodily or mental harm to members of the group;" Article 2(c) "deliberately inflicting on the group conditions of life calculated to bring about its physical destruction in whole or in part."

As symbols of the land and the dignity and continuation of their people, Uyghur women have become the symbolic and direct target of domination under China's colonialism. The ancient barbaric philosophy expressed in Legalism has also underpinned Chinese colonial ideology and reinforced the genocide. Consequently, preventing the continuation of and ultimately stopping the genocide in East Turkistan may require the decolonization of East Turkistan - as the genocide of its people stems directly from China's colonization of the region.

\section{Bibliography}

ABC News In-Depth, "How China is Creating the World's Largest Prison: Four Corners." YouTube video, 00:45:18. Uploaded July 16, 2019. Accessed May 15, 2021. https:// m.youtube.com/watch? feature=youtu.be\&v=t-axd1Ht 18 .

Bovingdon, Gardner. The Uyghurs: Strangers in Their Own Land, 1st ed. New York: Columbia University Press, 2019.

Buckley, Chris. "Brushing Off Criticism, China's Xi Calls Policies in Xinjiang 'Totally Correct.'” The New York Times, September 26, 2020. Accessed September 26, 2020. https:// www.nytimes.com/2020/09/26/world/asia/xi-jinping-china-xinjiang.html.

Byler, Darren. “Uyghur Love in a Time of Interethnic Marriage." SupChina, August 7, 2019. Accessed May 24, 2020. https://supchina.com/2019/08/07/uyghur-love-in-a-time-ofinterethnic-marriage/.

Dawut, Zumrat. "Conversation of Uyghur Women who are Married to Han Chinese in Tik Tok Video." Facebook, November 13, 2020, 2:38 p.m. Accessed May 18, 2021. https:// www.facebook.com/100034398679054/posts/397615751395044/?d=n.

\footnotetext{
72 Han Fei Tzu, "Guarding Against the Interior," in Vol. II of The Complete Works of Han Fei Tzu, trans. Wen Kuei Liao (London: Arthur Probsthain, 1939), 148.

73 The Prosecutor v. Jean-Paul Akayesu, Trial Judgement, September 2, 1998, International Criminal Tribunal for Rwanda (ICTR), ICTR-96-4-T, para. 497, accessed April 13, 2021, https://unictr.irmct.org/sites/unictr.org/files/casedocuments/ictr-96-4/trial-judgements/en/980902.pdf.

74 Ibid., paras. 507-508. See, in particular, “...[i]mposing measures intended to prevent births within the group..." include "...sexual mutilation, the practice of sterilization, forced birth control, separation of the sexes and prohibition of marriages. In patriarchal societies, where membership of a group is determined by the identity of the father, an example...is the case where, during rape, a woman of the said group is deliberately impregnated by a man of another group, with the intent to have her give birth to a child who will consequently not belong to its mother's group."
} 
Desjardins, Jeff. “Mapped: China's Most Ambitious Megaproject-The New Silk Road." Business Insider, March 19, 2018. Accessed September 14, 2020. https:// www.businessinsider.com/ chinas-most-ambitious-megaproject-the-new-silk-roadmapped-2018-3.

Doam (@doamuslims). “Chinese Official Interrogates Uyghur Muslim Girl.” Twitter, April 2, 2019, 12:02 p.m. Accessed May 15, 2021. https://twitter.com/doamuslims/status/ 1113109430177075200.

Ferris-Rotman, Amie, Aigerim Toleukhan, Emily Rauhala, and Anna Fifield. "China Accused of Genocide Over Forced Abortions of Uighur Muslim Women as Escapees Reveal Widespread Sexual Torture." The Independent, October 6, 2019. Accessed May 23, 2019. https://www.independent.co.uk/news/world/asia/china-uighur-muslim-womenabortions-sexual-abuse-genocide-a9144721.html.

Goff, Peter. "Become Family:' China Sends Officials to Stay with Xinjiang Minorities." The Irish Times, December 17, 2019. Accessed May 25, 2020. https://www.irishtimes.com/news/ world/asia-pacific/become-family-china-sends-officials-to-stay-with-xinjiangminorities-1.4118327.

Haitas, Daniel. "Shang Yang and Legalist Reform in The Ancient Chinese State of Qin." Challenges of the Knowledge Society 12 (2018), 524-531. Accessed March 222021. https: / / doaj.org/article/1675416918714f20b18ef6ce5890255f.

Haitiwaji, Gulbahar and Rozenn Morgat. "'Our Souls are Dead:' How I Survived a Chinese 'ReEducation Camp' for Uighurs." The Guardian, January 12, 2021. Accessed in January 28, 2021. https://www.theguardian.com/world/2021/jan/12/uighur-xinjiang-reeducation-camp-china-gulbahar-haitiwaji?CMP=share btn tw.

Han, Fei Tzu. "Guarding Against the Interior." In Vol. II of The Complete Works of Han Fei Tzu. Translated by Wen Kuei Liao. London: Arthur Probsthain, 1939.

Hidayat, Arslan (@arslan-hidayat). “Uyghur Girl Publicly Pimped.” Twitter, May 13, 2020, 8:06 p.m. Accessed May 15, 2021. https://twitter.com/arslan hidayat/status/ 1260723117682561025.

Hiebert, Maureen S. Constructing Genocide and Mass Violence: Society, Crisis, Identity. London: Routledge, 2017.

Hill, Matthew, David Campanale, and Joel Gunter. "'Their Goal is to Destroy Everyone:' Uighur Camp Detainees Allege Systematic Rape." BBC News, February 2, 2021. Accessed February 4, 2021. https://www.bbc.com/news/world-asia-china-55794071.

Hoja, Gulchehra. "Female Detainees at Xinjiang Internment Camps Face Sterilization, Sexual Abuse: Camp Survivor." Radio Free Asia, October 30, 2019. Accessed May 23, 2020. https://www.rfa.org/english/news/uyghur/abuse-10302019142433.html.

Huang, Anwei 黄安伟. “Xīnjiāng gǔlì mín hàn tōnghūn míhé mínzú máodùn: 新疆鼓励民汉通婚 弥合民族矛盾 [Xinjiang Encourages Marriage between the Han and Uyghurs to Bridge Ethnic Conflicts]." New York Times, September 3, 2014. Accessed May 23, 2020. https:// cn.nytimes.com/china/20140903/c03xinjiang/.

Kashijalian, Ashimu 阿西姆·卡什加里安. “Zhonguo shipin guang gao huyu bai ming wei wu er nu xing kuai jia han ren: 中国视频广告呼吁百名维吾尔女性快嫁汉人” [Chinese Video Advertisement Urgently Need 100 Uyghur Women to Marry Han Chinese Men]. Voice of America, August 22, 2020. Accessed August 22, 2020. https://www.voachinese.com/ a/china-xinjiang-inter-marriage-20200821/5553607.html.

Li, Mingxuan 李明轩. “Dàpī xīnjiāng wéizú rén bèi qiángzhì sòng wăng nèidì gōngchăng wàichū xū dài dìngwèi shǒu huán: 大批新疆維族人被強制送往內地工廠 外出須戴定位 手環” [A Large Number of Uyghurs in Xinjiang Force Sent to Factories in the Mainland, Wearing Tracking Bracelets]. Bitter Winter, March 9, 2020. Accessed May 25, 2020. https:// zh.bitterwinter.org/new-re-education-of-uyghurs-forced-labor-outsidexinjiang/. 
Li, Shao Xia 李绍霞, “An Analysis Report on Population Change in Xinjiang." Global Times, January 7, 2021. Accessed February 24, 2021. https://www.globaltimes.cn/page/ 202101/1212073.shtml.

“Xīnjiāng zú jì tōnghūn de diàochá yǔ fēnxī: 新疆族际通婚的调查与分析” [Investigation and Analysis of Intermarriage in Xinjiang]. Creaders.net (blog), May 9, 2014, accessed May 23, 2020, http://blog.creaders.net/u/3328/201405/181046.html.

Liu, Minghuan 刘明焕. “Xīnjiāng kuòdà hànhuà zhèngcè hànrén qǔ jiāng nŭ kě dé 50 mǔ tián jí 7 wàn yuán xiànjīn: 新疆扩大汉化政策 汉人娶疆女可得50亩田及7万元现金” [Xinjiang Expands Sinicization: Han People Marry Xinjiang Women Get 50 Mu Fields and 70,000 Yuan in Cash]. New Tang Dynasty Television: 新唐电视台, Oct. 30, 2019. Accessed May 24, 2020. https:/ / www.ntdtv.com/gb/2019/10/30/a102696368.html.

$\mathrm{Ma}$, Alexandra. "China is Reportedly Sending Men to Sleep in the Same Beds as Uighur Muslim Women while their Husbands are in Prison Camps." Business Insider, November 4, 2019. Accessed May 23, 2020. https://www.businessinsider.com/china-uighur-monitorhome-shared-bed-report-2019-11.

Millward, James A. Eurasian Crossroads: A History of Xinjiang, 1st ed. New York: Columbia University Press, 2007.

QQ Video News. “Xinjiang guniang wei sha bu neng tong hanzu nanzi jiehun: 新疆姑娘, 为啥不 能同汉族男子结婚? 来听下当地人怎么说” [Why Uyghur Women Cannot Marry Han Chinese]. November 27, 2019. Accessed May 21, 2020. https://v.qq.com/x/page/ f3026lh9hej.html.

Ramzy, Austin and Chris Buckley, "'Absolutely No Mercy:' Leaked Files Expose How China Organized Mass Detentions of Muslims." The New York Times, November 16, 2019. Accessed March 21, 2020. https://www.nytimes.com/interactive/2019/11/16/world/ asia/china-xinjiang-documents.html.

Ruser, Nathan and James Leibold. Family De-Planning: The Coercive Campaign to Drive Down Indigenous Birth-Rates in Xinjiang. Australian Strategic Policy Institute (ASPI), May 12, 2021. Accessed May 12, 2021. https://www.aspi.org.au/report/family-deplanningbirthrates-xinjiang.

Sauytbay, Sayragul and Alexandra Cavelius. The Chief Witness: Escape from China's Modern-Day Concentration Camps. Translated by Caroline Waight. Melbourne: Scribe, 2021.

Shang, Yang. The Book of Lord Shang: A Classic of the Chinese School of Law, trans. Jan Julius Lodewijk Duyvendak. London: Arthur Probsthain, 1928.

Short, Jonathan M. H. "Sexual Violence as Genocide: The Developing Law of the International Criminal Tribunals and the International Criminal Court." Michigan Journal of Race and Law 8, no. 2 (2003), Accessed May 15, 2021. https://repository.law.umich.edu/mjrl/ vol $8 /$ iss $2 / 5$.

Stubley, Peter. "Muslim Women 'Sterilised' in China Detention Camps, Say Former Detainees." The Independent, Aug 12, 2019. Accessed May 23, 2020. https:// www.independent.co.uk/news/world/asia/uighur-muslim-china-sterilisationwomen-internment-camps-xinjiang-a9054641.html.

The State Council Information Office of the People's Republic of China, Employment and Labor Rights in Xinjiang. White Paper. The People's Republic of China, September 17, 2020. Accessed January 28, 2021. http://english.www.gov.cn/archive/whitepaper/ 202009/17/ content WS5f62cef6c6d0f7257693c192.html.

Thum, Rian. The Sacred Routes of Uyghur History. Boston: Harvard University Press, 2014.

United Nations (UN). General Assembly Resolution 260, Convention on the Prevention and Punishment of the Crime of Genocide. December 9, 1948. UN Doc. A/RES/260(III).

. "Rwanda International Criminal Tribunal Pronounces Guilty Verdict in Historic Genocide Trial." Press Release, September 2, 1998. Accessed May 15, 2021. https:// www.un.org/press/en/1998/19980902.afr94.html. 


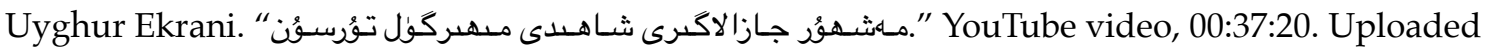
February 10, 2021. Accessed March 25, 2021. https://www.youtube.com/watch? $\mathrm{v}=\mathrm{ij} \times \mathrm{mwpK01Fk}$.

Uyghur Human Rights Project. China: Transfer of 400,000 Young Uyghur Women into Eastern China. Brussels: Human Rights Without Frontiers International, June 19, 2008. Accessed September 21, 2020. http:/ / www.david-kilgour.com/2008/Jun 202008 01.htm.

Uyghur Research Institute. Genocide in East Turkistan. Ankara: Uyghur Research Institute, February 2019. Accessed May 19, 2020. https://www.uysi.org/en/?p=774.

$\mathrm{Xi}$, Jinping. "Secure a Decisive Victory in Building a Moderately Prosperous Society in All Respects and Strive for the Great Success of Socialism with Chinese Characteristics for a New Era." Speech, Beijing, delivered at the 19th National Congress of the Communist Party of China, October 18, 2017. Accessed September 23, 2020. www.xinhuanet.com/ english/download/Xi Jinping's report at 19th CPC National Congress.pdf.

$\mathrm{Xu}$, Vicky Xiuzhong, Danielle Cave, James Leibold, Kelsey Munro, and Nathan Ruser. Uyghurs For Sale: "Re-Education," Forced Labour, and Surveillance Beyond Xinjiang. Australian Strategic Policy Institute, March 1, 2020. Accessed May 23, 2020. https:// www.aspi.org.au/report/uyghurs-sale.

Yao, Lao. "Families that Hang Together." China Daily, May 17, 2004. Accessed March 22, 2021. https://www.chinadaily.com.cn/english/doc/2004-05/17/content 331252.htm.

Zaidi, Afroze Fatima. "China is Forcibly Sterilising Muslim Women in Internment Camps, According to Former Detainees." The Canary, August 17, 2019. Accessed March 23, 2021. https:// www.thecanary.co/global/2019/08/17/china-is-forcibly-sterilising-muslimwomen-in-internment-camps-according-to-former-detainees/.

Zenz, Adrian. "The Karakax List: Dissecting the Anatomy of Beijing's Internment Drive in Xinjiang." Journal of Political Risk 8, no. 2 (February 2020). Accessed May 20, 2020 https: / / www.jpolrisk.com/karakax/.

--------. Sterilizations, IUDs, and Mandatory Birth Control: The CCP's Campaign to Suppress Uyghur Birthrates in Xinjiang (Washington D.C.: The Jamestown Foundation, June 2020). Accessed September 4, 2020. https://jamestown.org/product/sterilizations-iuds-andmandatory-birth-control-the-ccps-campaign-to-suppress-uyghur-birthrates-inxinjiang/.

. "Wash Brains, Cleanse Hearts:' Evidence from Chinese Government Documents about the Nature and Extent of Xinjiang's Extrajudicial Internment Campaign." Journal of Political Risk 7, no. 11 (November 2019). Accessed May 15, 2021. https:// www.jpolrisk.com/wash-brains-cleanse-hearts/. 